\title{
Guidelines for menopausal hormone therapy: Recommendations of the Polish Menopause and Andropause Society - state of knowledge as of December 2013
}

Rekomendacje Polskiego Towarzystwa Menopauzy i Andropauzy na temat hormonalnej $\begin{aligned} & \mathbf{P} \\ & \mathbf{T} \\ & \mathbf{M} \\ & \mathbf{A}\end{aligned} \| \boldsymbol{l}$

Małgorzata Bińkowska, Romuald Dębski, Tomasz Paszkowski, Magdalena Sendrakowska, Wojciech Zgliczyński

Having thoroughly reviewed the literature on this topic, Members of the Management of the Polish Menopause and Andropause Society present upto-date recommendations concerning menopausal hormone therapy (MHT).

Menopausal hormone therapy should be regarded as an important element of health care provided to peri- and postmenopausal women with a view to improving their quality of life and preventing adverse consequences of chronic estrogen deficiency.

Menopausal hormone therapy should be a part of health-promotion activities encompassing: prophylactic check-ups in order to detect risks and prevent the development of the most common age-related diseases or treat them at an early stage; recommendations regarding healthy diet and physical activity to maintain proper body weight with a concurrent emphasis on quitting smoking and reducing alcohol intake.

All women should be ensured access to reliable information on benefits and risks associated with MHT based on the assessment of their current health status, family and personal medical history, and potential risk of the development of chronic diseases and cancer.

The second half of the $20^{\text {th }}$ century saw a rapid growth in the frequency of MHT prescription. The publication of results obtained in the HERS trial (1998) [1], followed by the initial results of the WHI trial (2002) [2], undermined the fundamental assumptions of MHT as a method of primary and secondary prevention of chronic diseases. Subsequent years saw the publication of a number of detailed assessments taking into account women's age, time from the last menstrual period until the commencement of therapy, effects of MHT on different body organs and systems, treatment regimens, types and doses of hormones, route of administration and duration of therapy [3, 4]. Interpretations of fragmentary results of observational studies and $\mathrm{WHI}$ trials were often mutually contradictory, resulting in informational chaos and diverse approaches to MHT applied by physicians of different specialties.
Członkowie Zarządu Polskiego Towarzystwa Menopauzy i Andropauzy (PTMA) po wnikliwej analizie dostępnego piśmiennictwa przedstawiają aktualne zalecenia dotyczące stosowania hormonalnej terapii menopauzy (HTM).

Hormonalną terapię menopauzy należy traktować jako ważny element opieki zdrowotnej nad kobietą w okresie okołomenopauzalnym i po menopauzie, którego celem jest zarówno poprawa jakości życia, jak i zapobieganie niekorzystnym następstwom przewlekłego niedoboru estrogenów.

Hormonalna terapia menopauzy powinna być częścią działań prozdrowotnych, które obejmują: badania profilaktyczne pozwalające wykrywać zagrożenia i zapobiegać rozwojowi najczęstszych chorób charakterystycznych dla wieku bądź leczyć je we wczesnym stadium, zalecenia dotyczące zdrowej diety i aktywności fizycznej sprzyjające utrzymaniu należytej masy ciała, z równoczesnym naciskiem na zaprzestanie palenia papierosów i umiarkowane spożywanie alkoholu.

Każda kobieta powinna mieć możliwość uzyskania rzetelnej informacji o korzyściach i ryzyku HTM na podstawie oceny aktualnego stanu zdrowia, wywiadu rodzinnego i osobistego, potencjalnych zagrożeń rozwojem chorób przewlekłych i nowotworowych.

W drugiej połowie XX wieku obserwowano dynamiczny wzrost częstości stosowania HTM. Publikacje wyników badania HERS (Heart and Estrogen/Progestin Replacement Study) (1998) [1], a następnie pierwszych wyników badania WHI (Women's Health Initiative) (2002) [2] podważyły podstawowe założenia tej terapii jako pierwotnej i wtórnej prewencji chorób przewlekłych. W ciągu kolejnych lat ukazało się wiele szczegółowych analiz uwzględniających wiek kobiet, czas od ostatniej miesiączki do rozpoczęcia terapii, jej wpływ na poszczególne narządy i układy, schematy leczenia, rodzaj i dawki hormonów, drogę podania i czasokres terapii $[3,4]$. Interpretacje fragmentarycznych wyników badań obserwacyjnych i badania WHI bywały ze sobą sprzeczne, czego efektem był chaos informacyj- 
The first international consensus reached on the basis of opinions submitted by endocrinologists, gynecologists and cardiologists was the official position announced by the Polish Gynecology Society, Polish Cardiac Society and Polish Menopause and Andropause Society in 2007 [5].

During the past four years, there were attempts to systematize available knowledge, resulting in a number of position statements issued by various national and international expert groups. The recommendations they proposed, however, were not always consistent.

The year 2013 saw the publication of a core consensus statement prepared by international organizations operating in the field of women's health (American Society for Reproductive Medicine, Asia Pacific Menopause Federation, Endocrine Society, European Menopause and Andropause Society, International Menopause Society, International Osteoporosis Foundation, North American Menopause Society) [6]. The aim of the consensus statement is to assist national medical societies in the development of regional recommendations that incorporate local epidemiological, organizational and legal considerations. The present publication contains the guidelines referred to above (marked in bold) complete with a commentary.

The Polish Menopause and Andropause Society, an organization grouping physicians of different specialties, decided to prepare recommendations that could be used by Polish physicians to ensure optimal therapeutic management of peri- and postmenopausal women.

General recommendations for the therapeutic management of peri- and postmenopausal patients:

- MHT is the most effective treatment for vasomotor symptoms associated with menopause at any age, but benefits are more likely to outweigh risks for symptomatic women before the age of 60 years or within 10 years after menopause.

A review of the Cochrane Database, including results of 24 randomized studies, shows unequivocally that estrogens are the most effective agents alleviating hot flushes and excessive perspiration depending on their type and dose regimen, and after different durations of treatment (1-3 months) [7]. Other benefits include improved mood, decrease in depressive symptoms, reduction of muscle and joint pain, relief of sleep disorders and increased satisfaction with sexual life [8]. Menopausal hormone therapy has a favorable effect on the connective tissue, skin, joints and intervertebral discs [9, 10]. The reduced risk of developing Alzheimer's disease found in observational studies mainly applies to estrogen therapy that is commenced during the first several years after the menopause [11].

- Menopausal hormone therapy is effective and appropriate for the prevention of osteoporosis-related ny i odmienne postawy lekarzy różnych specjalności wobec stosowania HTM. Pierwszym w skali światowej konsensusem łączącym poglądy endokrynologów, ginekologów i kardiologów było stanowisko Polskiego Towarzystwa Ginekologiczngo (PTG), Polskiego Towarzystwa Kardiologicznego (PTK) i PTMA opracowane w 2007 roku [5].

W ciągu ostatnich czterech lat podjęto próby usystematyzowania posiadanej wiedzy, w wyniku czego powstało szereg stanowisk opracowanych przez różne krajowe i międzynarodowe gremia ekspertów, które często zawierały nie do końca spójne zalecenia.

W 2013 roku opublikowano szkielet wspólnego stanowiska międzynarodowych organizacji zajmujących się zdrowiem kobiety (American Society for Reproductive Medicine, Asia Pacific Menopause Federation, Endocrine Society, European Menopause and Andropause Society, International Menopause Society, International Osteoporosis Foundation, North American Menopause Society) [6], który ma służyć krajowym towarzystwom w opracowaniu regionalnych rekomendacji uwzględniających lokalne realia epidemiologiczne, organizacyjne i prawne. W niniejszej publikacji zawarto powyższe wytyczne (pogrubiona czcionka) wraz z komentarzem.

Polskie Towarzystwo Menopauzy i Andropauzy, jako organizacja zrzeszająca lekarzy różnych specjalności, postanowiło opracować zalecenia mogące służyć polskim lekarzom w optymalizacji postępowania z kobietą w okresie okołomenopauzalnym i po menopauzie.

Podstawowe założenia dotyczące postępowania z pacjentkami w okresie około- i pomenopauzalnym:

- Hormonalna terapia menopauzy jest najbardziej skuteczną metodą leczenia objawów naczynioruchowych w każdym wieku, przy czym relacja korzyści do ryzyka jest najlepsza do 60. roku życia lub do 10 lat od ostatniej miesiączki.

Przegląd bazy Cochrane obejmujący wyniki 24 badań z randomizacją wskazuje jednoznacznie, że estrogeny są najskuteczniejsze $w$ likwidacji uderzenia gorąca i nadmiernego pocenia, w zależności od rodzaju i dawki po różnym czasie podawania (1-3 miesiące) [7]. Obserwuje się również poprawę nastroju i zmniejszenie objawów depresyjnych, bóli mięśni i stawów, zaburzeń snu oraz wzrost satysfakcji z życia seksualnego [8]. Terapia wpływa korzystnie na tkankę łączną, skórę, stawy i krążki międzykręgowe [9, 10]. Zmniejszenie ryzyka rozwoju choroby Alzheimera stwierdzane w badaniach obserwacyjnych dotyczy głównie terapii estrogenowej rozpoczętej w ciągu kilku pierwszych lat po menopauzie [11].

- Hormonalna terapia menopauzy to skuteczna i właściwa metoda zapobiegania złamaniom osteoporotycznym u kobiet przed 60 . rokiem życia lub do 10 lat od ostatniej miesiączki. 
fractures in at-risk women before age 60 years or within 10 years after menopause.

Menopausal hormone therapy is the first-line management for the prevention and treatment of osteoporosis in women with premature/early menopause, and by 60 years of age. Standard-dose estrogen therapy lowers the risk of vertebral and hip fractures and other extravertebral fractures [12, 13]. Low and ultralow doses, regardless of the route of administration, have a beneficial effect on bone mass density [14]. The effect is sustained throughout the entire period of supplementation and subsides after the discontinuation of treatment [15].

- Randomized clinical trials and observational data as well as meta-analyses provide evidence that standard-dose estrogen-alone MHT may decrease coronary heart disease and all-cause mortality in women younger than 60 years of age and within 10 years of menopause. Data on estrogen plus progestogen MHT in this population show a similar trend for mortality but in most randomized clinical trials no significant increase or decrease in coronary heart disease has been found.

Estrogen therapy introduced during the so-called therapeutic window (i.e. $<60$ years of age or $<10$ years from the last menstrual period) has a beneficial effect on vascular function, cholesterol levels and carbohydrate metabolism, thus lowering the incidence of coronary episodes and myocardial infarctions, and reducing total mortality [3]. Menopausal hormone therapy increases insulin sensitivity, which decreases the risk of developing type 2 diabetes and metabolic syndrome [16]. A WHI trial has demonstrated a similar trend for combined estrogen plus progestogen therapy with respect to the effect on arteries in the younger patient subpopulation. In the randomized long-term Danish Osteoporosis Prevention Study (DOPS) published in 2012, the standard dose of estradiol with/without norethisterone acetate was found to have reduced hospital admissions due to myocardial infarction and heart failure, and general mortality [17].

Nevertheless, the initiation of MHT after 60 years of age or $>10$ years after the last menstrual period may lead to an increased frequency of coronary incidents, especially during the first two years of treatment.

- Local low-dose estrogen therapy is preferred for women whose symptoms are limited to vaginal dryness or associated discomfort with intercourse.

Symptoms of vulvovaginal atrophy including dryness, irritation, stinging, dysuria, dyspareunia and inflammation progressively increase with time since the menopause. Low-dose local estrogen therapy is more effective (80-90\%) than systemic treatment (75\%) [18]. Health benefits are also observed for recurrent urinary tract infections, overactive bladder
Terapia ta jest postępowaniem pierwszego rzutu w zapobieganiu i leczeniu osteoporozy u kobiet z przedwczesną/wczesną menopauzą oraz do 60. roku życia. Standardowa dawka estrogenów zmniejsza ryzyko złamań kręgosłupa, szyjki kości udowej i innych złamań pozakręgosłupowych [12, 13]. Dawka niska i ultraniska, niezależnie od drogi podania, wpływa korzystnie na gęstość masy kostnej [14]. Efekt ten utrzymuje się przez cały okres suplementacji i zanika po odstawieniu terapii [15].

- Wyniki badań klinicznych z randomizacją i badań obserwacyjnych oraz metaanaliz wskazują, że standardowa dawka terapii estrogenowej może zmniejszać częstość choroby naczyń wieńcowych oraz ogólną umieralność u kobiet młodszych (<60. roku życia lub do 10 lat od ostatniej miesiączki). Przy terapii estrogenowo-progestagenowej $w$ tej populacji obserwuje się podobny korzystny trend wskaźnika ogólnej umieralności, a w większości badań z randomizacją brak istotnego statystycznie wzrostu lub spadku ryzyka choroby naczyń wieńcowych.

Terapia estrogenowa rozpoczęta w okresie tzw. okna terapeutycznego (czyli < 60. roku życia lub < 10 lat od ostatniej miesiączki) wpływa korzystnie na czynność naczyń, stężenie cholesterolu oraz metabolizm węglowodanów, co zmniejsza częstość epizodów wieńcowych, zawałów mięśnia sercowego i ogólną umieralność [3]. Hormonalna terapia menopauzy zwiększa insulinowrażliwość, a w konsekwencji obniża ryzyko rozwoju cukrzycy typu 2 i zespołu metabolicznego [16]. Terapia estrogenowo-progestagenowa w badaniu WHI wykazywała podobny trend w odniesieniu do wpływu na naczynia tętnicze młodszej subpopulacji badanych. W wieloletnim badaniu z randomizacją DOPS (Danish Osteoporosis Prevention Study), opublikowanym w 2012 roku, standardowa dawka estradiolu z/bez octanu noretisteronu zmniejszała częstość hospitalizacji z powodu zawału mięśnia sercowego i niewydolności krążenia oraz ogólną umieralność [17].

Natomiast rozpoczęcie HTM po 60. roku życia lub > 10 lat od ostatniej miesiączki może prowadzić do wzrostu częstości występowania epizodów wieńcowych, zwłaszcza w ciągu pierwszych dwóch lat terapii.

- Niskodawkowa miejscowa terapia estrogenowa jest preferowana u kobiet, których objawy ograniczają się do suchości pochwy lub dyspareunii.

Objawy atrofii sromu i pochwy w postaci suchości, podrażnienia, pieczenia, dyzurii, dyspareunii i stanów zapalnych nasilają się wraz z upływem czasu od ostatniej miesiączki. Niskodawkowa miejscowa terapia estrogenowa jest bardziej skuteczna (80-90\%) niż terapia ogólna (75\%) [18]. Korzystne działanie dotyczy również nawracających zakażeń dróg moczowych, objawów pęcherza nadreaktywnego i nagłych parć na mocz. Terapia nie wymaga uzupełniania dodatkiem progestagenu. Nie podlega wyżej opisanym 
syndrome and sudden urinary urgency. The therapy requires no supplementation with progestogen. It is not subject to temporal constraints regarding the time-point of initiation of treatment.

- Estrogen as a single systemic agent is appropriate in women after hysterectomy but additional progestogen is required in the presence of a uterus. Progesterone or progestogen is used solely to protect the uterus from endometrial hyperplasia and endometrial cancer. WHI trials and some of the observational studies provide strong evidence for the claim that progestogens have a greater effect on the risk of breast cancer than estrogens.

- The option of MHT is an individual decision in terms of quality of life and health priorities as well as personal risk factors such as age, time since menopause and the risk of venous thromboembolism, stroke, ischemic heart disease and breast cancer.

Decisions on starting therapy and on the choice of treatment type must be individualized taking into account the woman's health status, her priorities, risk factors and potential dangers.

- The risk of venous thromboembolism and ischemic stroke increases with oral MHT but the absolute risk is rare below age 60 years. Observational studies point to a lower risk with transdermal therapy.

Venous thromboembolism is one of two main potential complications of $\mathrm{MHT}$. The risk rises with the woman's age, BMI (> $30 \mathrm{~kg} / \mathrm{m}^{2}-$ a nearly threefold increase) and estrogen dose. The risk level is the highest during the first year of therapy. A WHI trial demonstrated additional 11 cases/10,000 women for the estrogen/progestogen therapy, and four additional cases $/ 10,000$ women aged 50-59 years using estrogens alone. Some progestogens (particularly MPA - medroxyprogesterone acetate, norpregnane derivatives) and the continuous treatment regimen seem to have an adverse effect on the risk. A series of observational studies suggests that there is no increase in the risk of venous thromboembolism for transdermal therapy with the dose of $\leq 50 \mu \mathrm{g} /$ day [19]. Blood coagulation tests for thrombophilia might be recommended in patients with a significant family and personal history of the disease.

- The risk of breast cancer in women over 50 years associated with MHT is a complex issue. The increased risk of breast cancer is primarily associated with the addition of a progestogen to estrogen therapy and related to the duration of use. The risk of breast cancer attributable to MHT is small and the risk decreases after treatment is stopped.

The potential increase in breast cancer risk due to estrogen/progestogen therapy is small ( $<1$ case/1000 women/year) and corresponds to the risk caused by post-menopausal weight gain of $5 \mathrm{~kg}$ or regular consumption of strong alcohol [20]. The role of progesto- ograniczeniom czasowym co do czasu rozpoczęcia terapii.

- Kobietom po histerektomii należy zalecać wyłącznie estrogeny, gdyż dodatek progestagenu jest wymagany tylko przy zachowanej macicy.

Progesteron lub progestagen służą wyłącznie ochronie macicy przed rozwojem rozrostów i raka endometrium. Z wyników badań WHI i części badań obserwacyjnych płynie silne przesłanie, że progestageny mają większy wpływ na ryzyko wystąpienia raka piersi niż estrogeny.

- Hormonalna terapia menopauzy jest indywidualnym wyborem w aspekcie jakości życia i priorytetów zdrowotnych, jak również dodatkowych czynników, takich jak wiek, czas od ostatniej miesiączki, ryzyko żylnej choroby zakrzepowo-zatorowej (ŻChZZ), udaru mózgu, choroby niedokrwiennej serca i raka piersi. Podstawą podjęcia decyzji o terapii i jej rodzaju jest indywidualizacja uwzględniająca stan zdrowia kobiety, jej priorytety, czynniki ryzyka i potencjalne zagrożenia.

- Ryzyko ŻChZZ i udaru niedokrwiennego wzrasta przy doustnej HTM, ale bezwzględne ryzyko jest małe $u$ kobiet przed 60. rokiem życia. Badania obserwacyjne wskazują na mniejsze ryzyko przy zastosowaniu terapii przezskórnej.

Żylna choroba zakrzepowo-zatorowa jest jednym z dwóch najważniejszych potencjalnych powikłań HTM. Ryzyko rośnie wraz z wiekiem kobiety, BMI (> $30 \mathrm{~kg} / \mathrm{m}^{2}$ - wzrost prawie trzykrotny) oraz dawką estrogenów i jest największe $w$ pierwszym roku stosowania terapii. W badaniu WHI obserwowano dodatkowe 11 przypadków/10 000 kobiet dla terapii estrogenowo-progestagenowej, a 4 dodatkowe przypadki/10 000 wśród kobiet stosujących same estrogeny w przedziale wieku 50-59 lat. Niektóre progestageny (szczególnie MPA - octan medroksyprogesteronu, pochodne norpregnanowe) oraz schemat ciągły wydają się wpływać na to ryzyko niekorzystnie. Seria badań obserwacyjnych sugeruje brak wzrostu ryzyka ŻChZZ przy terapii przezskórnej dawką $\leq 50 \mu \mathrm{g} /$ dziennie [19]. Wykonywanie badań koagulologicznych w kierunku trombofilii może być zalecane przy obciążonym wywiadzie osobistym i rodzinnym.

- Ryzyko raka piersi u kobiet po 50. roku życia związane z HTM jest problemem złożonym. Wzrost ryzyka wiąże się głównie $z$ dodatkiem progestagenu do terapii estrogenowej i zależy od czasu jej stosowania. Ryzyko przypisane HTM jest niskie i obniża się po jej zaprzestaniu.

Prawdopodobny wzrost ryzyka rozwoju raka piersi pod wpływem terapii estrogenowo-progestagenowej jest mały (< 1 przypadek/1000 kobiet/rok) i odpowiada ryzyku wywołanemu przyrostem masy ciała po menopauzie o $5 \mathrm{~kg}$ czy regularnemu spożywaniu wysokoprocentowych napojów alkoholowych [20]. Bardzo istotna wydaje się rola progestagenu i sche- 
gen and its administration regimen seem to be of high importance. European observational studies point out that progesterone and dydrogesterone and sequential therapy have a better safety profile. Results obtained in the estrogen arm of the WHI study indicate that there is no increase in the risk of breast cancer after 7 years of therapy, however the high proportion of overweight and obese women could have had an impact on the high baseline risk [21]. European data suggest a slight increase in risk associated with long-term (15 years) use of MHT.

High mammographic density at baseline is an independent risk factor for breast cancer risk, and its further growth accompanying oral estrogen/progestogen therapy may decrease the sensitivity of prophylactic tests.

- The dose and duration of MHT should be consistent with treatment goals and safety issues and should be individualized.

The lowest effective estrogen dose adjusted to treatment goals and patients' priorities should be prescribed. Only NAMS guidelines provide that estrogen/progestogen therapy should be limited to 4-5 years on account of a slight increase in breast cancer risk after that period. The safety margin for estrogen therapy, however, seems to be much longer, covering up to about a dozen years. Updated recommendations issued by IMS (2013) [8] and the British Menopause Society (2013) [22], and recent guidelines prepared by the American College of Obstetricians and Gynecologists (ACOG) in 2014 [23], do not arbitrarily restrict the duration of MHT. The continuation of treatment depends on the patients' health status and individual risk profile, and the decision made by well-informed patients. PTMA experts claim that longer MHT is possible depending on women's symptoms and/or preferences, as long as individual long-term benefits arising from the improved quality of life and reduced risk of chronic diseases outweigh potential risks.

- In women with premature ovarian insufficiency, systemic MHT is recommended at least until the average age of the natural menopause.

Premature menopause affects $1 \%$ of women < 40 years of age, and early menopause $-5 \%$ of women $<45$ years of age. As a rule, treatment with at least standard doses (equivalent to $2 \mathrm{mg}$ of $\mathrm{E}_{2}$ orally), taken at least until 51 years of age, is effective in eliminating menopausal symptoms and reducing the risk of cardiovascular diseases and osteoporosis, probably also Alzheimer's disease. Both health benefits and the safety of treatment are very high.

- Current safety data do not support the use of MHT in breast cancer survivors.

No data are available on the safety of therapy. A recent randomized study indicates an increased risk of recurrence of breast cancer [24]. matu jego podawania. W europejskich badaniach obserwacyjnych stwierdzono lepszy profil bezpieczeństwa progesteronu i dydrogesteronu oraz terapii sekwencyjnej. Wyniki ramienia estrogenowego WHI wskazują na brak wzrostu ryzyka raka piersi po 7 latach terapii, jednak duży odsetek kobiet z nadwagą i otyłością mógł wpłynąć na wysokie ryzyko wyjściowe [21]. Dane europejskie sugerują niewielki wzrost ryzyka przy długotrwałym (15 lat) stosowaniu HTM. Wstępna wysoka gęstość mammograficzna piersi jest niezależnym czynnikiem ryzyka raka piersi, a jej dalszy wzrost pod wpływem doustnej terapii estrogenowo-progestagenowej może obniżać czułość badań profilaktycznych.

- Dawka i czas trwania HTM powinny być indywidualizowane, zależnie od celów terapii $\mathrm{i}$ jej bezpieczeństwa.

- Zalecana jest najmniejsza skuteczna dawka estrogenów zależna od celów terapii i priorytetów kobiety. Tylko rekomendacje North American Menopause Society (NAMS) proponują ograniczanie terapii estrogenowo-progestagenowej do 4-5 lat ze względu na nieznaczny wzrost ryzyka raka piersi po tym okresie, a dużo dłuższy wydaje się margines bezpieczeństwa dla terapii estrogenowej sięgający kilkunastu lat. Uaktualnione rekomendacje International Menopause Society (IMS) (2013) [8], British Menopause Society (2013) [22] oraz najnowsze zalecenia American College of Obstetricians and Gynecologists (ACOG) z 2014 roku [23] nie ograniczają arbitralnie czasu stosowania HTM - kontynuacja zależy od stanu zdrowia, indywidualnego profilu ryzyka i decyzji dobrze poinformowanej pacjentki. Zdaniem ekspertów PTMA dłuższe stosowanie HTM jest możliwe ze względu na objawy i/lub preferencje kobiety, gdy długotrwałe indywidualne korzyści wynikające z poprawy jakości życia i zmniejszenia ryzyka rozwoju chorób przewlekłych przeważają nad potencjalnym ryzykiem.

- U kobiet z przedwczesną niewydolnością jajników ogólnoustrojowa HTM jest zalecana co najmniej do średniego populacyjnego wieku menopauzy.

Przedwczesna menopauza dotyczy $1 \%$ kobiet < 40 . roku życia, a wczesna - 5\% < 45. roku życia. Z reguły skuteczna jest co najmniej dawka standardowa (odpowiadającą 2 mg $\mathrm{E}_{2}$ doustnie) w celu likwidacji objawów menopauzalnych, a zarazem zmniejszenia ryzyka rozwoju chorób sercowo-naczyniowych i osteoporozy, prawdopodobnie również choroby Alzheimera, stosowana przynajmniej do 51. roku życia. Korzyści i bezpieczeństwo terapii są bardzo duże.

- Na podstawie obecnie posiadanej wiedzy nie zaleca się stosowania HTM u kobiet po leczeniu raka piersi. Brakuje danych o bezpieczeństwie terapii. Ostatnie badanie z randomizacją wskazuje na wzrost ryzyka nawrotu raka piersi [24]. 


\section{Practical guidelines for the use of menopausal hormone therapy}

\section{Indications for menopausal hormone therapy}

1. Menopausal symptoms - moderate and severe. It has been indisputably proven that hormone treatment is the most effective method of eliminating vasomotor symptoms.

2. Symptoms of urogenital atrophy - typically vaginal dryness, dyspareunia, pollakiuria, nocturia, sudden urinary urgency, recurrent vaginitis and cystitis [18]. The position statement of NAMS suggests that the first-line therapy should be based on lubricants or long-acting vaginal moisturizers [25]. The recommendations issued by the British Menopause Society, however, provide that such treatment is much less effective than estrogen therapy [22]. Both systemic and topical estrogen treatments are effective. In some cases, using both routes of administration concurrently is the recommended strategy. If symptoms associated with urogenital atrophy are the only reason for starting MHT or if there are contraindications to systemic hormone treatment, topical estrogen therapy is an option.

3. Primary ovarian insufficiency: premature and early menopause - treatment should be continued until at least 51 years of age.

4. Osteoporosis - prevention and treatment, especially until 60 years of age. The therapeutic management is effective in preventing bone mass loss (also in ultra-low doses) and reducing the incidence of fractures, including vertebral and hip fractures (standard dose), only during the period of estrogen administration. After the discontinuation of treatment, acceleration of bone mass loss typical for the menopausal period is observed.

5. Prevention of systemic disorders associated with estrogen deficiency which increase in the postmenopausal period. Reduced risk of cardiovascular diseases, diabetes, metabolic syndrome, Alzheimer's disease and Parkinson's disease, provided that treatment is commenced in the perimenopausal period or during the first several years after the last menstrual period.

\section{Contraindications to menopausal hormone theropy}

In the light of the most recent recommendations, absolute contraindications to MHT include:

1) pregnancy,

2) undiagnosed abnormal uterine bleeding,

3) high risk of venous thromboembolism,

4) inadequately controlled hypertension,

5) history of myocardial infarction, unstable coronary disease,

\section{Praktyczne wytyczne dotyczqce zasad stosowania hormonalnej terapii menopauzy}

\section{Wskazania do hormonalnej terapii menopauzy}

1. Objawy menopauzalne - umiarkowane i nasilone. Bezdyskusyjnie udowodniono, że leczenie hormonalne jest najskuteczniejszym sposobem eliminacji objawów naczynioruchowych.

2. Objawy atrofii urogenitalnej - najczęściej suchość pochwy, dyspareunia, częstomocz, nykturia, parcia nagłe, nawracające stany zapalne pochwy i pęcherza moczowego [18]. Stanowisko NAMS sugeruje, że postępowaniem pierwszego rzutu jest stosowanie lubrykantów lub długo działających substancji nawilżających [25]. W stanowisku British Menopause Society znajduje się natomiast stwierdzenie, że leczenie takie jest znacznie mniej skuteczne niż estrogenoterapia [22]. Skuteczne jest zarówno podawanie estrogenów działających ogólnoustrojowo, jak i stosowanych lokalnie, a niekiedy zasadne jest równoczesne wykorzystanie obu dróg podawania hormonów. Jeżeli jedynym uzasadnieniem do HTM są objawy atrofii urogenitalnej lub w przypadku występowania przeciwwskazań do systemowego podawania hormonów, możliwe jest zastosowanie estrogenoterapii lokalnej.

3. Pierwotna niedoczynność jajników: przedwczesna i wczesna menopauza - leczenie powinno być kontynuowane co najmniej do ukończenia 51. roku życia.

4. Osteoporoza - zapobieganie i leczenie, szczególnie do 60. roku życia. Postępowanie skuteczne zarówno w prewencji utraty masy kostnej (też dawki ultraniskie), jak i zmniejszeniu częstości złamań, w tym kręgosłupa i szyjki kości udowej (dawka standardowa), wyłącznie w okresie podawania estrogenów. Po przerwaniu leczenia obserwuje się przyśpieszenie utraty masy kostnej typowe dla okresu menopauzy.

5. Protekcja zaburzeń ogólnoustrojowych związanych z niedoborem estrogenów, nasilających się w okresie pomenopauzalnym. Zmniejszenie ryzyka chorób układu sercowo-naczyniowego, cukrzycy, zespołu metabolicznego, choroby Alzheimera, choroby Parkinsona, pod warunkiem rozpoczęcia terapii w okresie okołomenopauzalnym lub w okresie kilku pierwszych lat po ostatniej miesiączce.

\section{Przeciwwskazania do hormonalnej terapii menopauzy}

W świetle najnowszych rekomendacji do bezwzględnych przeciwwskazań do stosowania HTM należą:

1) ciąża,

2) nieprawidłowe, niezdiagnozowane krwawienia z macicy,

3) wysokie ryzyko choroby zakrzepowo-zatorowej,

4) źle kontrolowane nadciśnienie tętnicze, 
6) history of cerebral stroke,

7) active liver disease, liver failure,

8) active or past history of estrogen-related cancer. A contraindication to progestogen therapy is meningioma.

\section{Available medicinal products}

The fundamental aspect of MHT is estrogen supplementation. At present, the Polish pharmaceutical market offers medicinal products containing estradio or estriol, however no products containing conjugated estrogens are marketed.

The only aspect justifying the introduction of progestogen therapy is protection against endometrial hyperplasia. Women who have had hysterectomy or supra-vaginal amputation of the uterine corpus should be treated with estrogens alone. Combined estrogen/ progestogen MHT carries a higher risk of breast cancer and has a lesser cardioprotective effect. The choice of progestogen and route of administration depends on the metabolic safety profile and patients' preferences. Progesterone- or dydrogesterone-based MHT is not only the most beneficial treatment modality in metabolic terms but it is also associated with the lowest risk of developing breast cancer. Testosterone-derived progestogens have a beneficial effect on bone mass density. There are studies suggesting that progestogens from this group may favorably impact the quality of sexual life. Products demonstrating antiandrogenic activity have applications in the treatment of hirsutism.

\section{Route of administration}

Hormone substitution can be administered orally, transdermally, intramuscularly and intravaginally. Currently, however, there are no estradiol-containing subcutaneous implants or vaginal rings available in Poland. Progestogen can also be delivered directly into the uterus by means of levonorgestrel intrauterine systems (LNG-IUS). The oral route of hormone administration is currently the most commonly used. On the one hand, oral administration is associated with a more pronounced beneficial effect on the parameters of lipid management. On the other hand, however, it is a more common trigger of thromboembolic complications.

Transdermal MHT can be administered in the form of patches or gels. Transdermal patches available on the Polish market contain either estradiol alone or in combination with norethisterone acetate. They can be used in sequential or continuous treatment regimens. Gels which are available in Poland contain estradiol alone.

Also, on the Polish market there is one intramuscular hormone product containing estradiol and prasterone sulfate (precursor for dehydroepiandrosterone synthe-
5) przebyty zawał serca, niestabilna choroba wieńcowa,

6) przebyty udar mózgu,

7) aktywna choroba wątroby, niewydolność wątroby,

8) estrogenozależna choroba nowotworowa, czynna lub przebyta.

Przeciwwskazaniem do podawania progestagenów jest oponiak mózgu.

\section{Dostępne preparaty}

Podstawowe znaczenie w HTM ma podaż estrogenów. W Polsce obecnie są dostępne preparaty lecznicze zawierające estradiol lub estriol, natomiast nie ma w sprzedaży preparatów estrogenów skoniugowanych.

Jedynym uzasadnieniem do podawania progestagenów jest protekcja rozrostów endometrium. Kobiety po usunięciu macicy lub nadszyjkowej amputacji trzonu macicy powinny otrzymywać same estrogeny. Złożona estrogenowo-progestagenna HTM wiąże się z wyższym ryzykiem rozwoju raka piersi i mniej korzystnym efektem kardioprotekcyjnym. Wybór rodzaju progestagenu i drogi jego podawania zależy od profilu bezpieczeństwa metabolicznego oraz preferencji pacjentki. Najkorzystniejsza metabolicznie i w najmniejszym stopniu zwiększająca ryzyko rozwoju raka piersi jest HTM zawierająca progesteron lub dydrogesteron. Progestageny pochodne testosteronu mają korzystny wpływ na gęstość masy kostnej. Istnieją opracowania sugerujące, że progestageny z tej grupy mogą mieć korzystny wpływ na jakość życia seksualnego. Preparaty o aktywności antyandrogennej mają zastosowanie $u$ kobiet $z$ hirsutyzmem.

\section{Droga podania}

Substytucja hormonalna może być prowadzona drogą doustną, przezskórną, domięśniową i dopochwową. Obecnie w Polsce nie są dostępne implanty podskórne i pierścienie dopochwowe zawierające estradiol. Progestagen może być również podany bezpośrednio do jamy macicy za pomocą systemów uwalniających lewonorgestrel (LNG-IUS). Najpowszechniejszym sposobem podawania hormonów jest podaż doustna. Wiąże się ona z wyraźniejszym, korzystnym wpływem na parametry gospodarki lipidowej, z drugiej strony jednak częściej prowadzi do występowania powikłań zakrzepowo-zatorowych.

Przezskórna HTM może być podawana w postaci plastrów lub żeli. Plastry dostępne w Polsce zawierają albo sam estradiol, albo estradiol z octanem noretysteronu, które mogą być stosowane w schemacie sekwencyjnym lub ciągłym. Żele dostępne w Polsce zawierają sam estradiol.

W Polsce dostępny jest jeden preparat podawany domięśniowo, co 4-6 tygodni, zawierający estradiol i siarczan prasteronu, czyli prekursor dla syntezy dehy- 
sis), for administration every 4-6 weeks. In women with preserved uterus, the product should be supplemented with progestogen, similarly to oral products containing only estradiol.

There are a number of medical reasons justifying the administration of transdermal or intramuscular dosage forms. These include: diseases of the liver and the biliary tract, digestive disorders, thyroid diseases, hypertension and hypertriglyceridaemia, and polypragmasia. It has been generally recognized that transdermal therapy does not increase the risk of thromboembolic complications or mammographic density.

Vaginal products which are available in Poland are known to act topically and have a negligible or no systemic effect. Persistent complaints accompanying vulvovaginal atrophy can be successfully eliminated by applying topical medications. It can be assumed that there are no absolute contraindications to local therapy of urogenital atrophy. Since topical treatment does not promote mucosal proliferation in the uterine corpus cavity, women with preserved uterus do not require progestogen supplementation. For recurrent vaginitis arising as a result of atrophy, concurrent administration of probiotics and/or topical hyaluronic acid products is justified.

\section{Dosage}

Menopausal hormone therapy can be administered at standard, low or ultra-low doses. Due to possible adverse reactions the goal should be to use the lowest individually adjusted effective hormone doses. Based on the current state of knowledge, the accepted standard dose is $2 \mathrm{mg}$ of estradiol $\left(E_{2}\right)$ for oral administration and $50 \mu \mathrm{g}$ of $\mathrm{E}_{2}$ for transdermal administration, the low dose is $1 \mathrm{mg}$ of $E_{2}$ for oral administration or 25-37.5 $\mu \mathrm{g}$ of $E_{2}$ for transdermal administration, and the ultra-low dose is $0.5 \mathrm{mg}$ of $\mathrm{E}_{2}$ orally or $14 \mu \mathrm{g}$ of $\mathrm{E}_{2}$ transdermally. The simplest method of assessing the efficacy of treatment is women's response and elimination of existing menopausal symptoms. There is a clear correlation between the dose of estrogens and the elimination of menopausal symptoms. The lowest dose delivering a statistically significant reduction in the frequency of hot flushes is the ultra-low dose, i.e. $0.5 \mathrm{mg}$ of estradiol. Further dose reductions lead to a loss of the therapeutic effect.

The therapeutic dose level can also depend on age and on the type of menopause (natural vs. surgical). Younger women more commonly require higher doses (standard or low), whereas postmenopausal patients typically derive greater benefits from lower doses (low or ultra-low).

\section{Menopausal hormone therapy regimen}

Menopausal hormone therapy in women who have undergone hysterectomy/amputation of the uterine cor- droepiandrosteronu. Preparat ten, tak samo jak leki zawierające sam estradiol, u kobiet z zachowaną macicą powinien być uzupełniany progestagenem.

Istnieje szereg uzasadnień medycznych zastosowania postaci przezskórnych lub domięśniowych. Należą do nich: choroby wątroby, dróg żółciowych i przewodu pokarmowego, choroby tarczycy, nadciśnienie tętnicze, hipertriglicerydemia i polipragmazja. W zasadzie przyjęto, że terapia transdermalna nie zwiększa ani ryzyka powikłań zakrzepowo-zatorowych, ani gęstości mammograficznej.

Dostępne w Polsce preparaty podawane drogą dopochwową działają lokalnie i mają minimalny albo wręcz żaden efekt ogólnoustrojowy. W przypadku występowania dokuczliwych dolegliwości wynikających ze zmian zanikowych pochwy i sromu można je skutecznie eliminować, stosując preparaty działające miejscowo. Można przyjąć, że nie ma bezwzględnych przeciwwskazań do lokalnej terapii atrofii urogenitalnej. Podaż tych leków nie prowadzi do proliferacji śluzówki jamy trzonu macicy, w związku z tym u kobiet z zachowaną macicą nie ma konieczności podawania progestagenów. W przypadku nawrotowych stanów zapalnych pochwy występujących w konsekwencji atrofii celowe jest równoczesne podawanie probiotyków i/lub lokalnych preparatów kwasu hialuronowego.

\section{Dawka}

Hormonalną terapię menopauzy można stosować w dawkach standardowych, niskich lub ultraniskich. Ze względu na możliwość występowania działań niepożądanych powinno się dążyć do stosowania najmniejszych indywidualnie skutecznych dawek hormonów. W świetle aktualnego stanu wiedzy za dawkę standardową uznaje się $2 \mathrm{mg}$ estradiolu $\left(\mathrm{E}_{2}\right)$ podawanego doustnie, a $50 \mu \mathrm{g}_{2}$ przezskórnie. Dawka niska to $1 \mathrm{mg} \mathrm{E}_{2}$ doustnie lub 25-37,5 $\mu \mathrm{g} \mathrm{E}_{2}$ przezskórnie. Dawka ultraniska to 0,5 $\mathrm{mg} \mathrm{E}_{2}$ doustnie lub $14 \mu \mathrm{g} \mathrm{E}_{2}$ przezskórnie. Najprostszą metodą oceny skuteczności leczenia jest reakcja kobiety i eliminacja występujących objawów menopauzalnych. Istnieje wyraźna zależność pomiędzy wysokością dawki estrogenów a stopniem eliminacji objawów menopauzalnych. Najniższą dawką zmniejszającą w sposób znamienny statystycznie częstość uderzeń gorąca jest dawka ultraniska, czyli 0,5 mg estradiolu. Dalsze zmniejszanie dawki prowadzi do utraty efektu terapeutycznego.

Dawka terapeutyczna może zależeć od wieku i typu menopauzy (naturalna czy operacyjna). Kobiety młodsze częściej wymagają podawania dawek wyższych - standardowych lub niskich, kobiety w okresie pomenopauzalnym częściej lepiej czują się przy niższych dawkach - niskich lub ultraniskich. 
pus consists of the continuous administration of a fixed dose of estrogen alone. In such women, there is no medical justification for the concurrent administration of progestogen or for the use of intermittent hormone therapy.

Women with preserved uterus can be prescribed MHT consisting of estrogen and progestogen in a sequential or continuous regimen. The choice of treatment regimen is independent of the route of hormone administration.

The sequential regimen may comprise hormone administration for 21 days: initially estrogens alone followed by estrogens combined with progestogen for the last 10-12 days. The 7-day break from hormone administration causes a hormone-withdrawal bleed. Due to a marked decrease in estrogen concentration occasionally accompanied by climacteric symptoms towards the end of the 7-day break period, the commonly used regimen involves continuous administration of estrogens combined with a progestogen course for 12-14 days. As soon as one pack of medication is finished, the next pack should be started. Progestogenwithdrawal bleeds occur usually during the first days after starting the next pack. It may also be acceptable to extend the period of using estrogens alone and induce bleeds on a two or three monthly basis.

Sequential regimens are most commonly used in women suffering from premature loss of ovarian function and during the perimenopausal period.

The continuous regimen involves concurrent use of estrogen and progestogen, usually at the lower single dose level. Continuous administration of progestogens induces atrophy of the uterine corpus mucosa and stops withdrawal bleeding. Nevertheless, there is a risk of uncontrolled uterine spotting. The frequency of spotting decreases with therapy, however it needs to be noted that the elimination of bleeding in continuous therapy is difficult to achieve in perimenopausal women, patients with uterine fibroids or a history of profuse menstrual bleeding, and women taking drugs which affect the coagulation system (anti-coagulation and anti-aggregation agents).

The continuous regimen is prescribed to women who no longer want uterine bleeding, in the postmenopausal period, preferably at least one year after the last menstruation. Women who want to maintain uterine bleeding and those who do not accept spotting associated with continuous therapy can be prescribed sequential MHT during the postmenopausal period.

The basis for the selection of MHT type should be individualization and adjustment of treatment to women's needs, risk factors and personal preferences.

\section{Menopausal hormone therapy - preliminary examinations}

1. Obtaining personal medical history (diseases, surgical procedures, medications, obstetric history

\section{Schemat terapii hormonalnej}

Hormonalna terapia menopauzy u kobiet po usunięciu macicy/trzonu macicy polega na ciągłym podawaniu stałej dawki samego estrogenu. $U$ kobiet tych nie ma żadnego uzasadnienia do równoległego podawania progestagenu czy też dokonywania przerw w stosowaniu hormonów.

U kobiet z zachowaną macicą HTM składająca się z estrogenu i progestagenu może być podawana w schemacie sekwencyjnym lub ciągłym. Wybór sposobu podawania hormonów jest niezależny od drogi ich przyjmowania.

Schemat sekwencyjny może polegać na podawaniu leku przez 21 dni, podczas których początkowo przyjmowane są same estrogeny, a przez ostatnie 10-12 dni estrogeny z progestagenem. W okresie 7-dniowej przerwy w podawaniu hormonów występuje krwawienie z odstawienia. Ze względu na wyraźne obniżenie stężenia estrogenów i występujące niekiedy dolegliwości wypadowe pod koniec 7-dniowej przerwy, powszechnie stosowany jest schemat podawania ciągłego estrogenów uzupełnionego 12-14-dniową wstawką progestagenną. Bezpośrednio po zakończeniu jednego opakowania rozpoczyna się przyjmowanie kolejnego. Do krwawienia z odstawienia progestagenu dochodzi najczęściej w pierwszych dniach kolejnego opakowania leku. Dopuszczalną wersją może być wydłużenie okresu podawania samych estrogenów i wywoływanie krwawień w odstępach dwu- lub trzymiesięcznych.

Schematy sekwencyjne stosowane są najczęściej u kobiet z przedwczesnym wygaśnięciem czynności jajników i u kobiet w okresie okołomenopauzalnym.

Schemat ciągły polega na równoległym podawaniu estrogenu i progestagenu zazwyczaj w niższej dawce jednorazowej. W konsekwencji ciągłej podaży progestagenów dochodzi do zaniku błony śluzowej trzonu macicy i nie występują krwawienia z odstawienia. Należy się jednak liczyć z ryzykiem pojawienia się niekontrolowanych plamień z macicy. Częstość ich występowania zmniejsza się w miarę trwania terapii, tym niemniej należy pamiętać, że brak krwawień w terapii ciągłej jest trudny do uzyskania u kobiet w okresie okołomenopauzalnym, z mięśniakami macicy, krwotocznymi miesiączkami w przeszłości oraz przyjmujących leki wpływające na układ krzepnięcia (leki przeciwkrzepliwe, antyagregacyjne).

Schemat ciągły stosowany jest u kobiet, które nie chcą już mieć krwawień z macicy, w okresie pomenopauzalnym, najlepiej co najmniej rok po ostatniej miesiączce. Kobietom chcącym zachować krwawienia z macicy oraz takim, które nie akceptują plamień przy terapii ciągłej, można w okresie pomenopauzalnym podawać HTM w schemacie sekwencyjnym.

Podstawą wyboru rodzaju HTM powinna być indywidualizacja - dostosowanie terapii do potrzeb, czynników ryzyka i preferencji kobiety. 
including gestational hypertension, preeclampsia, gestational diabetes) and family history (cancer, arterial and venous diseases).

2. Physical examination including measurements of body weight and BMI, pressure and waist-hip ratio.

3. Gynecological examination including cytological smear for cancer screening and transvaginal ultrasound test.

4. Palpatory breast examination and verification of most recent results of imaging tests (mammography and/or ultrasonography). A recent breast ultrasound or mammography result does not exempt the physician from the obligation to perform palpatory examination.

5. Determination of glucose and total cholesterol levels, and in the event of risk factors or abnormalities - OGTT and lipid profile test.

6. In case of doubt, assessment (even repeated assessment) of FSH and estradiol levels, and in selected cases also AMH level - in post-hysterectomy women using hormonal contraception, during hormone therapy.

7. In selected clinical situations, extension of the spectrum of tests to include assessment of TSH, transaminases, bilirubin or coagulation parameters, abdominal ultrasound examination, evaluation of the venous system of the lower extremities, examination of carotid arteries, densitometry or assessment of genetic predisposition to breast and ovarian cancer.

8. In the majority of cases, there is no need to perform the tests listed above prior to starting MHT.

\section{Menopausal hormone therapy - check-up examinations, monitoring of therapy}

The first check-up is recommended after 3-4 months of therapy. It is performed to review the efficacy of treatment and discuss side effects, adjust treatment components or dose, route of administration, and clarify doubts, if the patient has any. Every woman receiving MHT should have check-up examinations once a year as a minimum. After collecting the patient's history and performing a general physical examination followed by blood pressure and body weight measurements, the patient should undergo a gynecological examination. Cytological tests for cancer should be conducted on a three-year basis in low-risk groups and every year in increased risk groups. Transvaginal ultrasound testing is not required in patients with correct pattern and intensity of bleeding in sequential therapy or no bleeding in continuous therapy. Every patient should have palpatory breast examination on a yearly basis, and should be referred for imaging tests. The basic test used for breast cancer screening is mammography, however if mammographic results indicate higher sensitivity of ultrasound diagnostics, it can be substituted by or combined with radiological examination.

\section{Hormonalna terapia menopauzy - badania wstępne}

1. Zebranie medycznego wywiadu osobistego (choroby, operacje, leki, przeszłość położnicza, w tym nadciśnienie ciążowe, stan przedrzucawkowy, cukrzyca ciążowa) i rodzinnego (choroby nowotworowe, choroby naczyń tętniczych i żylnych).

2. Badanie fizykalne z pomiarem masy ciała i BMI, ciśnienia tętniczego, wskaźnika talia-biodro.

3. Badanie ginekologiczne z pobraniem wymazu cytoonkologicznego i przezpochwowym badaniem ultrasonograficznym.

4. Badanie palpacyjne piersi i weryfikacja aktualnych badań obrazowych (mammografia i/lub ultrasonografia). Aktualny wynik badania mammograficznego lub ultrasonograficznego piersi nie zwalnia lekarza z przeprowadzenia badania palpacyjnego.

5. Badania stężenia glukozy i cholesterolu całkowitego, a w razie występowania czynników ryzyka lub nieprawidłowości wykonanie testu doustnego obciążenia glukozą (oral glucose tolerance test - OGTT) i profilu lipidowego.

6. W sytuacjach wątpliwych ocena (nawet powtarzana) stężenia hormonu folikulotropowego (FSH) i estradiolu, a w wybranych przypadkach stężenia hormonu antymüllerowskiego (AMH) - $u$ kobiet po histerektomii, stosujących antykoncepcję hormonalną, w trakcie leczenia hormonalnego.

7. W wybranych sytuacjach klinicznych poszerzenie spektrum badań o: ocenę stężenia hormonu tyreotropowego (TSH), transaminaz, bilirubiny czy parametrów układu krzepnięcia, ultrasonograficzne badanie jamy brzusznej, ocenę układu żylnego kończyn dolnych, badanie tętnic szyjnych, densytometrię czy badanie predyspozycji genetycznych do wystąpienia raka piersi i jajnika.

8. W większości przypadków nie ma konieczności wykonywania ww. badań przed wdrożeniem HTM.

\section{Hormonalna terapia menopauzy - badania kontrolne, monitorowanie terapii}

Pierwsze badanie kontrolne zalecane jest po 3-4 miesiącach terapii. Służy ocenie skuteczności, występowania objawów ubocznych, korekcji składowych lub dawki, drogi podania oraz wyjaśnieniu ewentualnych wątpliwości. Każda kobieta otrzymująca HTM powinna najrzadziej raz do roku poddać się badaniom kontrolnym. Po zebraniu wywiadu i badaniu ogólnym, pomiarze ciśnienia tętniczego i masy ciała pacjentka powinna zostać zbadana ginekologicznie. Badanie cytoonkologiczne należy powtarzać w grupach niskiego ryzyka raz na 3 lata, w grupach podwyższonego ryzyka corocznie. Przezpochwowe badanie ultrasonograficzne nie jest niezbędne u pacjentek z prawidłowym rytmem i nasileniem krwawień w terapii 
The frequency of laboratory check-ups should be conditional on the results of preliminary tests. It must be noted that glucose and cholesterol screening in women above 45 years of age should be performed, as a minimum, every 5 years. If any abnormalities are identified, a 75-g glucose load test (OGTT) and a complete lipid profile test should be done. Women with diabetes, impaired glucose tolerance, obesity, hypertension and other atherosclerotic risk factors should undergo the test appropriately more frequently.

\section{Duration and discontinuation of therapy}

Following primary analysis of results obtained in the estrogen/progestogen arm of the WHI study, position statements were proposed indicating that the duration of treatment should be limited to 3, 5 or 7 years. A repeated analysis of the same material, and results recorded in the estrogen-alone arm, show that the only adverse element increasing together with the duration of $\mathrm{MHT}$ is the risk of breast cancer diagnosis in women treated with estrogens combined with progestogen.

A detailed review of the WHI study and a number of other studies have shown that the main reason for the increase in the risk of adverse vascular effects is late initiation of therapy. However, if treatment is started in the early postmenopausal period and continued on a long-term basis, not only is there no increase in risk, but the likelihood of cardiovascular and neurological complications and osteoporosis is in fact reduced. Thromboembolic complications occur mainly during the first year of oral therapy, and long-term continuation of treatment does not significantly increase the risk level. Consequently, there is a growing body of data demonstrating the legitimacy of continuing MHT for many years.

The discontinuation of treatment may be considered if contradictions to MHT are identified, if the patient does not accept the therapy or if there is no possibility of performing check-up examinations which are necessary to ensure that the therapy can be continued safely.

If a woman's sole motivation to start MHT was the elimination of climacteric symptoms, the only way to determine whether the treatment should be continued is stopping hormone supplementation temporarily so that the patient can perform a self-assessment of the severity of menopausal complaints. The self-assessment can be objectivized using a validated scale (e.g. Greene's climacteric scale). A recurrence of menopausal complaints decreasing the quality of life is an indication to resume therapy. sekwencyjnej i brakiem krwawień przy stosowaniu terapii ciągłej. Co roku pacjentka powinna mieć badane palpacyjnie gruczoły piersiowe i powinna być kierowana na badanie obrazowe. Podstawowym badaniem wykorzystywanym w przesiewowej diagnostyce raka piersi jest mammografia, tym niemniej, jeżeli jej wynik wskazuje na wyższą czułość diagnostyki ultrasonograficznej, może być ona wykonywana zamiennie lub łącznie z badaniem radiologicznym.

Częstość wykonywania kontrolnych badań laboratoryjnych zależy od wyników badań wstępnych. Należy pamiętać, że u kobiet po 45. roku życia przesiewową ocenę stężenia glukozy i cholesterolu powinno się przeprowadzać nie rzadziej niż co 5 lat. W przypadku nieprawidłowości należy przeprowadzić oznaczenie glukozy po doustnym obciążeniu 75 g (OGTT) oraz pełnego lipidogramu. Kobiety z cukrzycą, upośledzoną tolerancją glukozy, otyłością, nadciśnieniem tętniczym i innymi czynnikami ryzyka miażdżycy powinny mieć to badanie wykonywane odpowiednio częściej.

\section{Czas stosowania terapii i dyskontynuacja leczenia}

W konsekwencji pierwotnej analizy wyników gałęzi estrogenowo-progestagenowej badania WHI pojawity się stanowiska wskazujące na celowość ograniczenia czasu stosowania terapii do 3, 5 czy 7 lat. Kolejna analiza tego samego materiału oraz wyniki uzyskane w ramieniu estrogenowym wskazują, że jedynym elementem niekorzystnym rosnącym wraz z czasem stosowania HTM jest wzrost ryzyka rozpoznania raka piersi u kobiet otrzymujących estrogeny wraz z progestagenem.

Dokładna analiza badania WHI oraz szereg innych badań wykazały, że podstawową przyczyną wzrostu ryzyka występowania niepożądanych efektów naczyniowych jest zbyt późne rozpoczynanie terapii, a rozpoczęcie jej we wczesnym okresie pomenopauzalnym i długotrwała kontynuacja nie tylko nie zwiększa ryzyka, ale wręcz przeciwnie - zmniejsza prawdopodobieństwo występowania powikłań sercowo-naczyniowych, neurologicznych i osteoporozy. Powikłania zakrzepowo-zatorowe występują głównie w pierwszym roku stosowania terapii doustnej i długotrwała kontynuacja leczenia tego ryzyka już znacząco nie zwiększa. Zatem coraz więcej danych wskazuje na celowość wieloletniego utrzymywania HTM.

Uzasadnieniem do przerwania terapii jest wystąpienie przeciwwskazań do jej stosowania, brak akceptacji pacjentki lub niemożność wykonywania badań kontrolnych niezbędnych do bezpiecznej kontynuacji leczenia.

Jeżeli jedyną motywacją kobiety była eliminacja objawów wypadowych, to jedynym sposobem określenia celowości kontynuacji leczenia jest przerwa w suplementacji i samoocena nasilenia dolegliwości menopauzalnych, ewentualnie obiektywizowana za pomocą walidowanej skali (np. skala Greene'a). Ponownie występujące dolegliwości menopauzalne pogarszające jakość życia są wskazaniem do powrotu do terapii. 


\section{Selected references/Wybrane pozycje piśmiennictwa}

1. Hulley S, Grady D, Bush T, et al. Randomized trial of estrogen plus proges tin for secondary prevention of coronary heart disease in postmenopau sal women. Heart and Estrogen/progestin Replacement Study (HERS) Research Group. JAMA 1998; 280: 605-613.

2. Rossouw JE, Anderson GL, Prentice RL, et al.; Writing Group for the Women's Health Initiative Investigators. Risks and benefits of estrogen plus progestin in healthy postmenopausal women: principal results From the Women's Health Initiative randomized controlled trial. JAMA 2002; 288: 321-333.

3. Rossouw JE, Prentice RL, Manson JE, et al. Postmenopausal hormone therapy and risk of cardiovascular disease by age and years since menopause. JAMA 2007; 297: 1465-1477.

4. Hodis HN, Collins P, Mack WJ, et al. The timing hypothesis for coronary heart disease prevention with hormone therapy: past, present and future in prospective. Climacteric 2012; 15: 217-228.

5. Kornacewicz-Jach Z, Czarnecka D, Rynkiewicz A, et al. Stanowisko zespołu ekspertów Polskiego Towarzystwa Ginekologicznego, Polskiego Towarzystwa Kardiologicznego oraz Polskiego Towarzystwa Menopauzy i Andropauzy na temat wpływu terapii hormonalnej okresu menopauzalnego na układ sercowo-naczyniowy. Prz Menopauz 2007; 5: 253-257.

6. Villiers TJ, Gass MLS, Haines CJ, et al. Global consensus statement on menopausal hormone therapy. Climacteric 2013; 16: 203-204.

7. MacLennan AH, Broadbent JL, Lester S, et al. Oral oestrogen and combined oestrogen/progestagen therapy versus placebo for hot flushes. Cochrane Database Syst Rev 2004; 4: CD002978.

8. de Villiers TJ, Pines A, Panay N, et al.; International Menopause Society. Updated 2013 International Menopause Society recommendations on menopausal hormone therapy and preventive strategies for midlife health. Climacteric 2013; 16: 316-337.

9. Calleja-Agius J, Brincat MP. Effects of hormone replacement therapy on connective tissue: why it is important? Best Pract Res Clin Obstet Gynaecol 2009; 23: 121.

10. Calleja-Agius J, Muscat-Baron Y, Brincat MP. Estrogens and the intervertebral disc. Menopause Int 2009; 15: 127-130.

11. North American Menopause Society. The 2012 hormone therapy position statement of: The North American Menopause Society. Menopause 2012; 19: 257-271.

12. Cauley JA, Robbins J, Chen Z, et al. Effects of estrogen plus progestin on risk of fracture and bone mineral density: the Women's Health Initiative randomized trial. JAMA 2003; 290: 1729-1738.
13. Anderson GL, Limacher M, Assaf AR, et al. Effects of conjugated equine estrogen in postmenopausal women with hysterectomy: the Women's Health Initiative randomized controlled trial. JAMA 2004; 291: 1701-1712.

14. Bagger YZ, Tanko LB, Alexandersen P, et al. Two to three years of hormone replacement therapy in healthy women have long-term prevention effects on bone mass and osteoporotic fractures: the PERF study. Bone 2004; 34: 728-731.

15. Stevenson JC; International Consensus Group on HRT and Regulatory Issues. HRT, osteoporosis and regulatory authorities Quis custodiet ipsos custodies? Hum Reprod 2006; 21: 1668-1671.

16. Mauvais-Jarvis F, Clegg DJ, Hevener AL. The role of estrogens in control of energy balance and glucose homeostasis. Endocr Rev 2013; 34: 309-338.

17. Schierbeck LL, Rejnmark L, Tofteng CL, et al. Effect of hormone replacement therapy on cardiovascular events in recently postmenopausal women: randomized trial. BMJ 2012; 345: e6409.

18. Sturdee DW, Panay N; International Menopause Society. Recommendations for the management of postmenopausal vaginal atrophy. Climacteric 2010; 13: 509-522.

19. Renoux C, Dell'Aniello S, Suissa S. Hormone replacement therapy and the risk of venous thromboembolism: a population study. J Thromb Haemost 2010; 8: 979-986.

20. Chlebowski RT, Anderson GL, Gass M, et al. Estrogen plus progestin and breast cancer incidence and mortality in postmenopausal women. JAMA 2010; 304: 1684-1692.

21. Anderson GL, Chlebowski RT, Aragaki AK, et al. Conjugated equine estrogen and breast cancer incidence and mortality in postmenopausal women with histerectomy: extended follow-up of the Women's Health Initiative randomized placebo-controlled trial. Lancet Oncol 2012; 13 : 476-486.

22. Panay N, Hamoda H, Arya R, et al.; British Menopause Society and Women's Health Concern. The 2013 British Menopause Society \& Women's Health Concern recommendations on hormone replacement therapy. Menopause Int 2013; 19: 59-68.

23. The American College of Obstetricians and Gynecologists. Practice Bulletin Number 141. Management of Menopausal Symptoms. Obstet Gynecol 2014; 123: 202-216.

24. Holmberg L, Iversen OE, Rudenstam CM, et al.; HABITS Study Group. Increased risk of recurrence after hormone replacement therapy in breast cancer survivors. J Natl Cancer Inst 2008; 100: 475-482.

25. Management of symptomatic vulvovaginal atrophy: 2013 position statement of The North American Menopause Society. Menopause 2013; 20: 888-902. 